\title{
Connecting Jordan to GCC Power Grid: Creation of Geopolitical "Power" Grid
}

\author{
Mikiyasu Nakayama (Corresponding author) \\ Graduate School of Frontier Sciences, The University of Tokyo \\ 5-1-5 Kashiwano-ha, Kashiwa, Chiba 277-8563, Japan \\ Tel: 81-4-7136-4869 Fax: 81-4-7136-4842Ｅ-mail: nakayama@k.u-tokyo.ac.jp
}

\begin{abstract}
Hirotaka Fujibayashi
Graduate School of Frontier Sciences, The University of Tokyo

5-1-5 Kashiwano-ha, Kashiwa, Chiba 277-8563, Japan

E-mail: h.fujibayashi13@gmail.com

Daisuke Sasaki

Graduate School of Frontier Sciences, The University of Tokyo

5-1-5 Kashiwanoha, Kashiwa-shi, Chiba 277-8563, Japan

Tel: 81-90-6718-9295Ｅ-mail: k-sasaki@mail.ecc.u-tokyo.ac.jp
\end{abstract}

Received: March 19, 2017 Accepted: April 7, 2017 Published: April 12, 2017

doi:10.5296/jad.v3i2.10966 URL: https:// doi.org/10.5296/10.5296/jad.v3i2.10966

\begin{abstract}
Jordan agreed in May 2016 to join the existing Gulf countries' power grid (GCC Power Grid). This planned connection with the GCC countries has some political importance, aside from simply promoting trade of electricity between Jordan and GCC countries. This article aims at finding out the "embedded agenda" behind the planned connection of power grids between Jordan and the GCC countries. It was found that Jordan's participation in the GCC Power Grid is advantageous for Saudi Arabia and Jordan for trading electricity between two countries in the future. The planned connection of the power grid signifies the strengthened relation between two countries, without having troubles to be caused (among GCC's member states) by Jordan's official participation in the GCC as a new member. Jordan is so vulnerable
\end{abstract}




\section{Macrothink

to oil price surge, the development of alternative energies represented by renewable energies has a very significant meaning. Jordan could export electricity derived from renewable sources to neighboring countries in the future. Jordan historically serves as a buffer zone among countries with different interests and religions in the Middle East. Connection Jordan to the GCC Power Grid seems to have an utmost political importance for the GCC member states, particularly Saudi Arabia.

Keywords: Gulf Cooperation Council (GCC), Jordan, Power Grid, Renewable Energy Sources 


\section{Introduction}

On the 19th May 2016, Jordan signed a memorandum of understanding with the Gulf Cooperation Council Interconnection Authority (GCCIA) to join the existing Gulf countries' power grid (GCC Power Grid) (Jordan Times, 2016a). The purpose of the planned connection is to enable Jordan to import electricity from Saudi Arabia if needs arise (Jordan Times, 2016b).

The economic benefit is one of the major motivations of establishing the GCC Power Grid. The connected countries may enjoy improving economic efficiency by reducing the required operating reserves, which are needed to ensure that the overall power grid operated with an acceptable level of reliability. The GCC Power Grid is supposed to be expanded eventually into other regions like North Africa, Europe and EJLIST (Egypt, Jordan, Iraq, Lebanon, Syria, and Turkey), which could provide it with various economic benefits (Al-Asaad \& Ebrahim, 2008).

The authors, however, wonder if the alleged economic benefit is actually the primary aim of the plan. The planned connection is widely publicized as "bridging" Jordan and GCC countries. Minister of Energy and Mineral Resources of Jordan told the mass media "the interconnection between the Arab states is a key factor in reducing costs and increasing the efficiency of the grid", stressing that "the connection to the GCC grid will bring several economic benefits to Jordan" (Jordan Times, 2016a). However, the study by Bowen et. al. (2007), which examined the economic benefits of inter connections (by Iran, Iraq, Jordan, Syria, Turkey and Egypt) suggests that the economic benefits to be secured by Jordan would be much smaller than ones to be enjoyed by other nations. Connecting Jordan to the GCC countries may not lead to large and immediate economic benefits for Jordan.

It accordingly seems safe to assume that the connection with the GCC countries as a whole could have political importance as the primary aim, aside from promoting trade of electricity between Jordan and Saudi Arabia to seek economic benefits as the secondary objective.

The main objective of this study is thus to understand "embedded agenda", namely political benefit as the primary objective of the planned connection of power grids between Jordan and the GCC countries.

\section{Electricity in GCC Countries and Jordan}

\subsection{GCC Power Grid}

In 1981, six countries (Bahrain, Kuwait, Oman, Qatar, Saudi Arabia and the United Arab Emirates) in the Arab Gulf region formed the Gulf Cooperation Council (GCC) in response to the regional security concerns (Koch, 2010). "GCC has achieved noticeable progress in aspects of regional integration, even moving forward on such projects as a common market and a common currency, and begun to play an increasing role in political and security-related matters at the sub-regional level" (Koch, 2010, p. 24). One of the by-products of GCC formulation was the development of the GCC Power Grid to connect the electricity sectors with the member states. 


\section{MInstitute ${ }^{\text {Mink }}$}

The GCC Power Grid was completed in 2011 under the sponsorships of the GCC Interconnection Authority (GCCIA), which was established in 2001 (Energy Digital, 2015). By establishing the power grid, however, the GCC countries intended to reorganize and privatize their power sectors, which would eventually lead to energy trading not only among the GCC's member states but also among other participating nations of other power grids such as the Pan-Arab, European and Mediterranean. This would lead the Gulf Arab region to become a major exporter of electricity (Al-Asaad, Al-Mohaisen \& Sud, 2006; El-Katiri, 2011).

Once the GCC electricity is well operated, energy trading will be initiated and the ultimate ambition for the GCC countries (Energy Digital. 2015), the GCC power grid serves mostly for emergency power supply among member states, rather than trading of electricity, with utilization factor of as low as $8 \%$ (GCCIA, 2014). One of the major challenges against energy trading market is energy price distortions due to implicit and explicit government subsidies, differences in national energy policies and local regulations towards cross-border power trade. (Wakalat Anba'a al-Emarat, 2015).

\subsection{Prospects of Future Electricity for Production in Jordan}

Jordan depends on fuel imports about $96 \%$ of the energy needs. In particular, Jordan relies on $80 \%$ of its electricity generation on natural gas imported from Egypt. Moreover, Jordan trades electricity with neighboring countries. The annual power generation of Jordan in 2014 was 18,480 GWh, while Jordan imported 434.9 GWh and exported 63.7 GWh in the same year (National Electric Company, 2015). El-Katiri (2014) indicated that "Economic losses incurred by rising fossil fuel consumption in the MENA region are also visible in net importing countries (NICs) (p 5).” Also, Energy Charter Secretariat (2010) pointed out, "As Jordan lacks domestic natural gas and conventional crude oil resources, their high shares in the national energy mix imply a striking dependence on energy imports of more than $90 \%$. In 2007 , total spending on energy imports was equivalent to around $20 \%$ of the gross domestic product (Energy Charter Secretariat, 2010). Based on the previous literature Jordan seems to be very vulnerable to oil price surge.

In 2014, Jordan traded electricity exclusively for Egypt, while the trade was conducted between Jordan and Syria from 2004 to 2011 (National Electric Company, 2015). Because of persistent civil war in Syria from 2011 and the lack of political stability in Egypt since the Arab Spring of 2011, Jordan has much less potential of trading electricity for these neighboring countries. Initiating trade of electricity with Saudi Arabia sounds a reasonable choice for Jordan under the prevailing circumstances.

Besides the need for finding suitable electricity trading partners, Jordan is ahead of other Arab countries to promote power generation from renewable energy sources. In fact, Jordan has a significant potential of power generation by renewable energy sources, such of these sources: solar and wind power generation. Anagreha and Bataineh (2011) stated as a result of their technical analysis, "Jordan has a great potential of wind and solar in various locations. Therefore, projects deal with the practical implementation of the wind and solar resources in the country are highly recommended (p 2232)." Thus, Jordan seems to have a huge potential 
to export electricity derived from renewable sources. Jordan passed the Renewable Energy and Energy Efficiency Law in 2012 and introduced Feed-in-Tariffs to encourage power generation by renewable energy sources. Jordan may increase the share of power generation from renewable energy sources from about $0.3 \%$ in 2012 to more than $47 \%$ in the year 2022 (Fichter, Kern, \& Trieb, 2013). Jordan also plans to provide 30 percent of the country's electricity by 2030 and ultimately to export energy (Stratfor, 2016).

The question to be asked is if Jordan may become an exporter of electricity to Saudi Arabia and other GCC countries? Bloomberg New Energy Finance (2011) suggests that "solar energy is already a viable option for power generation in the region where it can be used to replace the burning of oil for power generation, as long as that oil is valued at the international selling price" (p1). Emirates Solar Industry Association (2012) supports this argument, saying "Solar is cheaper than an open- cycle peaking unit at gas prices above \$5/MMBtu (equivalent to oil at around \$30/barrel) (p8)," and moreover "With oil or LNG prices above US\$13/million British thermal units (MMBtu) (about \$80/barrel oil), solar PV projects become commercially viable in the generation mix without the need for subsidies. This break-even price will fall as solar power costs continue to drop (p13)."

As for ever reading the study by the Emirates Solar Industry Association (2012); it was noticed that it was based on the assumption that "the Levelized cost of electricity (LCOE) from solar PV in typical MENA climates is estimated as $15.4 \mathrm{US} \notin / \mathrm{kWh}$ (p8)." The drastic decrease in LCOE for solar power generation was observed after the publication of the study in 2012. A study by Frankfurt School-UNEP Centre (2016), reported that "In the second half of 2015, the global average Levelized cost of electricity for crystalline silicon PV was $\$ 122$ per MWh, down from \$143 in H2 2014 (p11)" and "200MW plant in Dubai being built by ACWA Power International, awarded a contract in January 2015 at just $\$ 58.50$ per MWh (p11)". Also, International Renewable Energy Agency (IRENA) (2016a) pointed out, "From 2010-2015, the capacity-weighted average LCOE decreased 58\%. The LCOE of utility-scale PV systems is expected to continue its downward trend (p.48)." Jordan also enjoyed the downward trend of LCOE from solar PV. According to the PV Insider (2015), Jordan's second round of renewable energy bids in early 2015 for four $50 \mathrm{MW}$ plants resulted in the lowest four tariffs of 6.13 to 7.67 US cents $/ \mathrm{kWh}$.

After these low tenders, the Middle East Solar News (2015) suggested that a tariff of 6 to 8 US cents/kWh is the new target for utility-scale solar projects in the Middle East. In May 2016, Mohammed bin Rashid Al Maktoum Solar Park of the Dubai Electricity and Water Authority (DEWA), have a generation capacity of 5,000 megawatts, DEWA received the bid of as low as 2.99 US cents/kWh for the park's 800MW third phase (Graves, 2016). In October 2016, for the $300 \mathrm{MW}$ solar power project in Mexico, was the lowest bid 2.699 US cents/kWh (Cleantechies, 2016). Although increasing the cost-effectiveness of the solar power generation and absence of the anti-renewable energy development "oil producing industry lobby", Jordan is considered a better position than Saudi Arabia to promote power generation through renewable energy sources. 


\subsection{Long-Term Plans/Visions and Renewable Energy}

In the past five decades, diversification of the connected countries' economies away from heavy dependence on oil and gas has been a significant matter for the GCC countries. "Within the context of the GCC countries, economic diversification means reducing heavy dependence on the oil sector by developing a non-oil economy, non-oil exports, and non-oil revenue sources. By implication, it also means reducing the leading role of the public sector in the GCC economies by promoting the growth of the private sector" (ESCWA, 2001, p. vii). Due to varying in scope, the level of detail and quality among GCC countries, it would be difficult to say that those diversification strategies succeeded in reforming their economic structures. However, all of the countries are very enthusiastic for economic diversification, and have published long-term plans and visions to reach main targets: The Economic Vision 2030 for Bahrain; State Vision Kuwait 2035; Omani Vision 2020; Qatar national Vision 2030; Saudi Vision 2030; the UAE's Vision 2021; Hvidt, 2013).

The development of renewable energy sector is essential for the GCC countries' economic diversification. Renewable energy has a potential to address not only the unclear future after the oil era but also the current instability of oil-dominant society. For the countries formed by rentier-system, it is important for the governments to provide nationals employment opportunities in the public sector facing the increasing population vis-à-vis shrinking public sectors. In this respect, the development of renewable energy sectors will create opportunities for recruitment, especially for poor Gulf economies. According to IRENA study, the development of renewable energy sector could potentially create an average of 140,000 jobs every year, and about 210,000 people could have employment opportunities (IRENA, 2016b). As such, the development of renewable energy also has a potential in terms of employment in the Gulf monarchies.

\subsection{Shadowed Energy Sector Rehabilitation in Saudi Arabia}

In spite of being the world's second biggest oil producer, Saudi Arabia has an aim to be the main player in the development of renewable energy. Saudi Arabia planned to make a $100 \%$ switch from fossil fuels to renewable energy with an investment of other alternatives of fossil fuels such as nuclear power. (Harvey, 2012). Therefore, the kingdom promised in 2012 to install $41 \mathrm{GWh}$ (which would make up around $50 \%$ of energy mix) of solar energy generation capability by 2032 (PV Magazine, 2016), But plans were failed due to unexpected lower oil prices. Therefore, Saudi Arabia is still focusing on the mission of renewable energy development as a vision which should be attained on 2030. Recently, Saudi Arabia has sought to develop gas resources and renewable energy to provide fuel for power plants and industries and to make available more oil to sell overseas (Mahdi \& Nereim, 2016). With a plan of being a global powerhouse of renewable energy in the future, Saudi Arabia aims to generate 9.5 GWh of renewable energy as an initial target to build up a competitive renewable energy sector according to the Vision of 2030 (KSA, 2016). To do so, the country seeks to localize a significant portion of the renewable energy value chain to promote liberalization of the fuels market gradually under the King Salman Renewable Energy Initiative (KSA, 2016).

However, many economists and journalists are doubtful about the possibility of Saudi's 
Vision 2030 (Wagner, 2016). That is because Saudi Arabia promised before, for decades, about economic diversification, but there is no change. Dr. Moritz Borgmann, the Cleantech Advisory of Apricum, said "there is still a certain risk that the lofty renewable energy targets of the new Saudi Vision 2030 program do not see the light of day due to delays or disruptions, for example, because of down-prioritization, through political dissent among Saudi government stakeholders, the eruption of fights about the unclear succession rules in the royal family or a worsening of the regional security situation" (Borgmann, 2016, para. 19).

Complex conditions in Saudi Arabia would also influence the Saudi's oil giant company (Aramco). Although there is no doubt that Aramco is one of the most important players in Saudi energy sector, and the company said it would be seeking to play a key role in the kingdom's ambitious plan to become one of the world's top clean energy producers (The New Arab, 2016). From point of view of the authors, if the kingdom has conducted reforms in the current energy sector, it seems to be obvious to cause structural changes among Saudi domestic stakeholders, and the power of Saudi's oil giant company (Aramco) would be influenced - diminish to some extent (The New Arab, 2016). It is quite difficult to adopt the total consequences of energy reforms. Thus, renewable energy targets are perceived with a skepticism.

\section{Security Concerns in the Arab Region}

\subsection{Jordan as a Buffer Zone among Countries}

Jordan depends on the natural gas which imported from Egypt via the Arab Gas Pipeline to generate as much as $80 \%$ of the national electricity production. This reliance was threatened in April 2011. The Arab Gas Pipeline was attacked by Bedouin activists, which disrupted the supply of natural gas from Egypt to Jordan for 45 days (Pelham, 2012). Saudi Arabia then granted Jordan around $\$ 400$ million to compensate the expenditure by purchasing natural gas from alternative sources such as Azerbaijan. This incident made Jordan inclination towards the GCC membership (Stonaker, 2011).

The GCC, in fact, invited two Arab kingship -Jordan and Morocco- to join the organization in 2011, at the onset of the Arab Spring. "The GCC recognizes both Jordan and Morocco as having financial stress and has already pledged millions in grants to help develop their economic sector. Saudi Arabia was reported to have given Jordan a \$400 million dollar grant and there was a discussion that during the GCC meeting in September 2011 the figure of $\$ 2$ billion dollars per country per year for economic aid and development over the next five years was under consideration" (Gastaldo, 2012: p 67). While Morocco showed little interest in the offer, Jordan showed its keen interest in joining the GCC (Ryan, 2014).

Gastaldo (2012) said that the decision to invite can be considered to be the result of a combination of political and fortuitous events due to the Bahraini uprising and the ouster of Tunisia and Egypt's Presidents. Jordan and Saudi Arabia established the Coordination Council in April 2016, after the meeting between King Salman bin Abdul-Aziz Al Saud and King Abdullah II held in Riyadh. They expressed that two countries face the same challenges regarding their security (Jordan Times, 2016c). Therefore, the alliance is very important to 
face any dangerous event which could happen in the future (Halaby, 2016).

In the face of common threats, membership expansion or an updated version of the GCC +2 negotiation - with Egypt and Jordan - has been long considered with the impact of the United States' interest (Patrick, 2011). Therefore, "the membership of Jordan had already been under consideration in the past, although there are disputed accounts as to whether or not Jordan had been refused in the past or it had never requested consideration" (Gastaldo, 2012, p 82).

The GCC countries have historically been crucial actors for the Arab region or the Middle East as the declaration of Crown Prince of Abu Dhabi in the GCC-US Summit in 2016 April (Wakalat Anba'a al-Emarat, 2016). Therefore, the plan of expanding the GCC member and strengthen of connection would be necessary due to economies and security challenges (Al-Tamamy, 2015).

\subsection{Enhancing Geopolitical "Power" Grid}

The collaboration between Jordan and Saudi Arabia makes Saudi Arabia's investments possible in Jordan's nuclear and solar energy sectors as well as uranium enrichment (Halaby, 2016). Jordan is a country with little fossil fuel reserves, well situated to develop power stations with non-fossil fuel energy sources rather than Saudi Arabia, where stakeholders in the fossil fuel businesses are against development of non-thermal power stations. Saudi Arabia plans to help Jordan in the nuclear power sector and in mining Jordan's uranium resources in exchange for energy trade and access to the uranium reserves (Stratfor, 2016). Furthermore, Saudi Arabia is one of top five investors in Jordan, with more than $\$ 10$ billion spent on projects, like infrastructure, transportation, energy, financial and commercial sectors as well as tourism construction (Halaby, 2016).

GCC countries is a cohesive group which maintains close ties to the West, and contain similar political, economic and social systems (Koch, 2010: 33). However, in terms of external policy, GCC countries are not totally allied. Oman and Qatar have pursued external policies independent of Saudi Arabia (Ryan, 2014).

Jordan's participation in the GCC Power Grid is advantageous, “Jordan plays a stabilizing role in the region; serving as an intermediary when neighboring countries need a host or a dealmaker; and providing qualified Jordanian workers for filling open vacancies for companies and countries, especially in the Gulf." (Comolet, 2014). In addition, the planned connection of the power grid signifies the strengthened relation between Saudi Arabia and Jordan as the interest is for both, without having troubles to be caused by GCC's member states as a new member. The existence of the GCC's electricity interconnection is not limited to "enhance further cooperation between the GCC Country's utilities and regulators", but also "act as a gateway towards achieving regional and pan-Arab power pools. Thus, promoting social, economic, environmental development and cooperation among the Middle East and North African countries" (Al-Asaad, 2009, p 64; Al-Asaad, Al-Mohaisen \& Sud, 2006, p 6). It thus seems to the authors that the primary objective of Jordan's participation in the GCC's Power Grid is in the sphere of politics. 


\section{Conclusion}

Jordan is vulnerable to oil price surge. Development of alternative energies represented by renewable energies has a very significant meaning. Jordan could export electricity derived from renewable sources to neighboring countries in the future. In this context, the planned Jordan's participation in the GCC's Power Grid seems because of economic interest. However, due to various structural issues in the power sector of the GCC countries, it may take a long time for Jordan and the GCC member states to secure economic benefits of Jordan's joining the GCC Power Grid. The authors thus assume that the primary, in a sense hidden, objective of the project lies in the sphere of politics. In other words, the very trigger of Jordan's participation in the GCC's Power Grid seems to be so political that the project can proceed in a relatively short period. It should be recalled that Jordan has not become a member state of the GCC despite Jordan's close alliance with the GCC members. It was presumably because of the country has substantially lower Gross domestic product (GDP) than GCC member states. Accepting Jordan as an official member may shadow the GCC, which has the prestige as an economic bloc of wealthy countries (Gastaldo, 2012). It thus sounds unrealistic, at least for the time being, to have Jordan's official participation in GCC. Jordan's participation in the GCC Power Grid thus has an utmost advantage from political viewpoints, as it clearly shows the enhanced political power of the GCC countries. Such political importance is more significant in these days than before, under the prevailing instability in the Middle East, particularly because Jordan is supposed to play a stabilizing role in the Middle East, especially in the Gulf Arab.

\section{Acknowledgement}

This study was partly funded by the Agency of Natural Resources and Energy of the Ministry of Economy, Trade, and Industry, and the Graduate School of Frontier Sciences at the University of Tokyo.

\section{References}

Al-Asaad, H. K. (2009). Electricity Power Sector Reform in the GCC Region. The Electricity Journal, 58-64. https://doi.org/10.1016/j.tej.2009.08.013

Al-Asaad, H. K., Al-Mohaisen, A. I., \& Sud, S. (2006, November). GCC Power Grid: Transforming the GCC Power Sector into a major energy trading market. In Cigre Conference, Abu Dhabi, UAE (pp. 27-29).

Al-Asaad, H., \& Ebrahim, A. A. (2008). The GCC Power Grid: Benefits \& Beyond. Oil, Gas \& Energy Law Journal (OGEL), 6(3). Retrieved from http://www.gccia.com.sa/Data/PressRelease/Press_13.pdf

Al-Tamamy, S. (2015, March 31). GCC Membership Expansion: Possibilities and Obstacles. Al Jazeera Centre for Studies. Retrieved from http://studies.aljazeera.net/en/dossiers/2015/03/201533171547520486.html\#

Anagreh, Y., \& Bataineh, A. (2011). Renewable energy potential assessment in Jordan. Renewable and Sustainable Energy Reviews, 15(5), 2232-2239. 
http://dx.doi.org/10.1016/j.rser.2011.02.010

Bahrain Economic Development Board. (2008). Our Vision: The Economic Vision 2030 for Bahrain. Manama: Bahrain EDB. Retrieved from https://www.evisa.gov.bh/Vision2030Englishlowresolution.pdf

Bloomberg New Energy Finance. (2011). Sun Sets on Oil for Gulf Power Generation, White Paper, Bloomberg New Energy Finance, 19 January 2011.

Borgmann, M. (2016, May 9). Potentially Game-Changing Saudi Arabian Government Restructuring Bolsters 9.5 GW Renewable Energy Target by 2023. APRICUM. Retrieved from http://www.apricum-group.com/saudi-arabia-announces-9-5-gw-renewable-energytarget-new-king-salman-renewable-energy-initiative/

Bowen, B., Sparrow, F. T., Irwin, M. W., Sharifi, A., \& Zobaa, A. F. (2007). The Economic Benefits of a Fully Integrated Middle East Power Grid, Middle East Economic Association (MEEA) 6th International Conference, Zayed University, Dubai, UAE, 14 to 16 March 2007. Retrieved from https://www.researchgate.net/publication/237802531

Chabkoun, M. (ed.). (2014, March 31). Gulf Cooperation Council's Challenges and Prospects. Al-Jazeera Centre for Studies. Retrieved from http://studies.aljazeera.net/mritems/ Documents/2015/3/31/2015331131534662734Gulf\%20Cooperation.pdf

Cleantechies. (2016). Fotowatio Wins 300 MW Solar In Mexico Auction At US $\$ 2.69 / \mathrm{kWh}$. Cleantechies. Retrieved 31 October, 2016, from http://cleantechies.com/ 2016/10/31/fotowatio-wins-300-mw-solar-in-mexico-auction-at-us\%C2\%A22-69kwh/

Comolet, E. (2014). Jordan: The Geopolitical Service Provider. Washington DC: The Brookings. Retrieved from https://www.brookings.edu/wp-content/uploads/2016/06/ArabEconPaper4Comolet-v2.pdf

Economic and Social Commission for Western Asia (ESCWA). (2001). Economic Diversification in the Oil-Producing Countries: The Case of the Gulf Cooperation Council Economies. New York: United Nations, ESCWA.

El-Katiri, L. (2011). Interlinking the Arab Gulf: Opportunities and Challenges of GCC Electricity Market Cooperation. Oxford: Oxford Institute for Energy Studies.

El-Katiri, L. (2014). A Roadmap for Renewable Energy in the Middle East and North Africa. Oxford: Oxford Institute for Energy Studies.

Emirates Solar Industry Association. (2012). Sunrise inAbu Dhabi: Emirates Solar Industry Association. Retrieved from https://www.pwc.com/m1/en/publications/solar-in-the-desert-incollaboration-with-emirates-solar-industry-association.pdf

Energy Charter Secretariat. (2010). Jordan: Regular Review of Energy Efficiency Policies 2010. Brussels: Energy Charter Secretariat.

Energy Digital. (2015, December 11). The power of six - a super grid in the gulf. Energy Digital. Retrieved from http://www.energydigital.com/utilities/3998/The-power-of-six- 
a-super-grid-in-the-gulf

Fichter, T., Kern, J., \& Trieb, F. (2013). The challenges of Jordan's electricity sector. In: Jordanien und Deutschland - Über die Vielfalt kultureller Brücken Reichert Verlag (pp. 199-204). Retrieved from http://elib.dlr.de/85640/1/DeutschJordanischeFestschrift_ Topic_Energie.pdf

Frankfurt School-UNEP Centre. (2016). Global Trends in Renewable Energy Investment 2016. Frankfurt: Frankfurt School-UNEP Centre. Retrieved from http://fs-unep-centre.org/sites/default/files/publications/globaltrendsinrenewableenergyinvest ment2016lowres_0.pdf

Gastaldo, A. F. (2012). The Gulf Cooperation Council's New Members: The Impact of Inviting the Hashemite kingdom of Jordan and the Kingdom of Morocco into the GCC.

GCCIA. (2014). Developing Power Trade through the GCC Interconnector. 3rd Power Trade Forum, Abu Dhabi, 28-29. Retrieved September, 2014, from http://www.gccia.com.sa/Data/PressRelease/Press_38.pdf

Graves, L. (2016). Costs tumble as Dubai's Mohammed bin Rashid Al Maktoum Solar Park sets the mark. Abu Dhabi: The National. Retrieved 1 May, 2016, from http://www.thenational.ae/business/energy/costs-tumble-as-dubais-mohammed-bin-rashid-almaktoum-solar-park-sets-the-mark

GSDP (General Secretariat for Development Planning). (2008). Qatar National Vision 2030. Doha: GSDP. Retrieved from http://www.mdps.gov.qa/en/qnv/Documents/QNV2030_ English_v2.pdf

Halaby, J. J. (2016). Jordan, Saudi Arabia move closer in the face of regional upheaval. The Arab Weekly. 8 May 2016. Retrieved from http://www.thearabweekly.com/News-\&Analysis/4983/Jordan,-Saudi-Arabia-move-closer-in-the-face-of-regional-upheaval

Harvey, F. (2012, October 19). Saudi Arabia reveals plans to be powered entirely by renewable energy. The Guardian. Retrieved from https://www.theguardian.com/ environment/2012/oct/19/saudi-arabia-renewable-energy-oil

Hvidt, M. (2013, January). Economic diversification in GCC countries: Past record and future trends. Kuwait Programme on Development, Governance and Globalisation in the Gulf States (The London School of Economics and Political Science). Retrieved from https://pdfs.semanticscholar.org/31b8/254fea903f9a074496ad225596b874e0eb33.pdf

IRENA (International Renewable Energy Agency). (2016a). The Power to Change: Solar and Wind Cost Reduction Potential to 2025. Abu Dhabi, United Arab Emirates: IRENA.

IRENA (International Renewable Energy Agency). (2016b). Renewable Energy Market Analysis: The GCC Region. Abu Dhabi, United Arab Emirates: IRENA. Retrieved from http://www.irena.org/DocumentDownloads/Publications/IRENA_Market_GCC_2016.pdf

Jordan Times. (2016a). Jordan signs deal to connect to GCC power grid. Amman: Jordan 


\section{MInstitute Macrothink $^{\text {Int }}$}

Journal of Asian Development

ISSN 2377-9594

2017, Vol. 3, No. 2

Times. Retrieved 19 May, 2016, from http://www.jordantimes.com/news/local/jordansigns-deal-connect-gcc-power-grid

Jordan Times. (2016b). Jordan to connect to GCC power grid through Saudi Arabia. Amman: Jordan Times. Retrieved 17 May, 2016, from http://www.jordantimes.com/news/local/jordanconnect-gcc-power-grid-through-saudi-arabia

Jordan Times. (2016c). Jordan, S. Arabia establish joint coordination council. Amman: Jordan Times. Retrieved 27 April, 2016, from http://jordantimes.com/news/local/jordans-arabia-establish-joint-coordination-council

Kingdom of Saudi Arabia (KSA). (2016). Vision 2030. Retrieved from http://vision2030.gov.sa/download/file/fid/417

Koch, C. (2010). The GCC As A Regional security Organization. KAS International Reports.

Mahdi, W., \& Nereim, V. (2016, June 7). Saudi Arabia Scales Back Renewable Energy Goal to Favor Gas. Bloomberg. Retrieved from https://www.bloomberg.com/news/articles/2016-06-07/saudi-arabia-scales-back-renewable-e nergy-target-to-favor-gas

Middle East Solar News. (2015). Results from Jordan's 200MW Round II solar PV tender. The Middle East Solar Industry Association. Retrieved 20 May, 2015, from http://www.mesia.com/results-from-jordans-200mw-round-ii-solar-pv-tender

National Electric Company. (2015). Presentation at EURELECTRIC Conference: The MENA Energy Transition. Brussels. Retrieved 06 May, 2015, from www.eurelectric.org/media/ 175589/al- daradkah.pdf

Patrick, Neil. (2011, November). The GCC: Gulf state integration or leadership cooperation? Kuwait Programme on Development, Governance and Globalisation in the Gulf States (The London School of Economics and Political Science). Retrieved from http://www.lse.ac.uk/middleEastCentre/kuwait/documents/Partrick\%202\%20paper.pdf

Pelham, N. (2012). Sinai: The Buffer Erodes. London: Chatham House (The Royal Institute of International Affairs).

PV Insider. (2015). Jordan PV tariffs drop 50\% in the second tender round. London: PV Insider. Retrieved 1 June, 2015. from http://analysis.pv-insider.com/jordan-pv-tariffs-drop50 -second-tender-round

PV Magazine. (2016, April 26). Saudi Arabia announces new renewable energy target with few details of deployment. Retrieved from https://www.pv-magazine.com/2016/04/26/saudi-arabia-announces-new-renewable-energy-ta rget-with-few-details-of-deployment_100024304/

Reiche, D. (2010). Energy Policies of Gulf Cooperation Council (GCC) countries - possibilities and limitations of ecological modernization in rentier states. Energy Policy, 38, 2395-2403, https://doi.org/10.1016/j.enpol.2009.12.031 


\section{Macrothink}

Journal of Asian Development

ISSN 2377-9594 2017, Vol. 3, No. 2

Ryan, C. (2014). Jordan, Morocco and an Expanded GCC, Washington DC: Middle East Research and Information Project. Retrieved from http://www.merip.org/jordanmorocco-expanded-gcc

Stonaker, M. E. (2011). Jordan looks to GCC for energy security. Al Arabiya News. Retrieved 9 July, 2011, from https://www.alarabiya.net/articles/2011/07/09/156768.html

Stratfor. (2016). Understanding Saudi Alliances Practically. Austin: Stratfor. Retrieved 7 September, 2016, from https://www.stratfor.com/analysis/understanding-saudi-alliancespractically

The New Arab. (2016, November 2). Saudi Arabia wants to become a global renewable energy powerhouse. Retrieved from https://www.alaraby.co.uk/english/news/2016/11/2/ saudi-arabia-wants-to-become-global-renewable-energy-powerhouse

United Arab Emirates Cabinet. (2010). UAE Vision 2021: United in Ambition and Determination. Abu Dhabi: Government of United Arab Emirates. Retrieved from https://www.vision2021.ae/sites/default/files/uae-vision2021-brochure-english.pdf

Wagner, R. L. (2016, May 1). Saudi 'Vision 2030' Sparks Praise, Skepticism. The Arab Weekly. Retrieved from https://13martyrs.wordpress.com/2016/05/01/saudi-vision20309-sparks-praise-skepticism/

Wakalat Anba'a al-Emarat. (2015). Fourth Regional Power Trade Forum discusses the roadmap to start intra-GCC energy trade. Abu Dhabi: Wakalat Anba'a al-Emarat (Emirates News Agency). Retrieved 17 December, 2015, from http:/www.wam.ae/en/news/emirates/ 1395289372435.html

Wakalat Anba'a al-Emarat. (2016). GCC has a historic role in preserving regional security, Abu Dhabi: Wakalat Anba'a al-Emarat (Emirates News Agency). Retrieved 21 April, 2016, from http://www.wam.ae/en/news/emirates/1395294495140.html

\section{Copyright Disclaimer}

Copyright for this article is retained by the author(s), with first publication rights granted to the journal.

This is an open-access article distributed under the terms and conditions of the Creative Commons Attribution license (http://creativecommons.org/licenses/by/4.0/). 